\title{
Playing to the Gallery: Emotive Rhetoric in Parliaments
}

\author{
MORITZ OSNABRÜGGE Durham University \\ SARA B. HOBOLT London School of Economics and Political Science \\ TONI RODON Universitat Pompeu Fabra
}

\begin{abstract}
7 esearch has shown that emotions matter in politics, but we know less about when and why politicians use emotive rhetoric in the legislative arena. This article argues that emotive rhetoric is one of the tools politicians can use strategically to appeal to voters. Consequently, we expect that legislators are more likely to use emotive rhetoric in debates that have a large general audience. Our analysis covers two million parliamentary speeches held in the UK House of Commons and the Irish Parliament. We use a dictionary-based method to measure emotive rhetoric, combining the Affective Norms for English Words dictionary with word-embedding techniques to create a domain-specific dictionary. We show that emotive rhetoric is more pronounced in high-profile legislative debates, such as Prime Minister's Questions. These findings contribute to the study of legislative speech and political representation by suggesting that emotive rhetoric is used by legislators to appeal directly to voters.
\end{abstract}

\section{INTRODUCTION}

W hen and why do legislators use emotive rhetoric? In today's political landscape many prominent politicians, such as Donald Trump, rely heavily on emotional appeals, both positive ("Make America Great Again") and fear-inducing ("They're bringing drugs. They're bringing crime. They're rapists") (Nai and Maier 2018). However, we know less about whether and how emotions are used strategically in parliamentary speeches. Legislatures are at the heart of representative democracy and parliamentary debates serve as an important forum for politicians to publicly express their views and communicate with voters (Martin and Vanberg 2008; Mayhew 1974; Proksch and Slapin 2012; Victor 2011). Hence, understanding the role of emotions in these debates is important. Our argument is that politicians are most likely to employ such rhetoric when their speeches reach a large public audience - that is, when they are speaking to the electorate. We leverage the variation in the public profile of legislative debates to test this proposition empirically. In low-profile legislative debates, we contend that legislators will primarily seek to address colleagues within the parliament and consequently emotive rhetoric should be less pronounced. In contrast, in high-profile debates parliamentarians have an incentive to use emotive rhetoric to attract the attention of a larger audience and appeal to them, with

Moritz Osnabrügge (D), Assistant Professor, School of Government and International Affairs, Durham University, moritz.osnabruegge@ durham.ac.uk.

Sara B. Hobolt (D), Sutherland Chair in European Institutions and Professor, Department of Government, London School of Economics and Political Science, s.b.hobolt@lse.ac.uk.

Toni Rodon (D), Assistant Professor, Department of Political and Social Sciences, Universitat Pompeu Fabra, toni.rodon@upf.edu.

Received: October 06, 2020; revised: March 10, 2021; accepted: April 14, 2021. First published online: May 24, 2021. not only policy substance but also more emotive language. This argument builds on two strands of literature. First, recent work on political speech has studied how politicians adapt the style and the tone of their speeches to appeal to the electorate. For example, Spirling (2016) argues that cabinet members began using more simple language after the extension of the franchise in the Second Reform Act in Britain in 1867, because they sought to appeal to the less educated citizens who were now part of the electorate. Rheault et al. (2016) show that government parliamentarians tend to use more positive language, while opposition parliamentarians use more negative language (see also Crabtree et al. 2020). Slapin and Kirkland (2020) provide evidence that rebel parliamentarians in the House of Commons use simpler language and more first-person pronouns. Thus, these studies suggest that politicians consider various aspects of their rhetoric beyond policy content.

Second, studies on the role of emotions in individuallevel decision making have shown that emotional appeals can be an effective persuasive tool for politicians to influence how voters process information and respond to their messages (Bakker, Schumacher, and Rooduijn 2021; Bless, Mackic, and Schwarz 1992; Brader 2005; Weeks 2015). Moreover, as qualitative studies of political rhetoric have documented, emotions are often used by politicians to convey their message, persuade their constituents, or trigger a reaction from the opponent (Crines 2013; Finlayson and Martin 2008; Prior 2018). Building on these strands of literature, we argue that emotive rhetoric is one of the devices that legislators employ in speeches that have a larger audience.

We test this proposition by analyzing a unique dataset of nearly one million parliamentary speeches between 2001 and 2019 in the lower house of the UK Parliament, the House of Commons. As one of the oldest parliaments in the world, the UK Parliament is an ideal institutional setting in which to study parliamentary speeches. Our analysis focuses on the House of Commons, which is the elected and more powerful of 
the two legislative chambers of the UK Parliament. ${ }^{1}$ Importantly, we can leverage the fact that the legislative debates in the House of Commons differ in terms of their profile and the size of the audience. This allows us to compare emotive rhetoric across different types of debates.

We measure emotive rhetoric by combining the Affective Norms for English Words (ANEW) dictionary with word-embedding techniques (Bradley and Lang 2017; Mikolov, Sutskever, et al. 2013; Rice and Zorn 2019). Our results confirm that legislative debates with larger public audiences - such as Prime Minister's Questions (PMQs) and the opening day of the Queen's Speech debates-are characterized by higher levels of emotive rhetoric. We find this effect holds even when holding constant individual speakers and policy topics. Furthermore, we demonstrate the generalizability by replicating our analysis using one million parliamentary speeches from the lower house of the Irish Parliament, Dáil Éireann, where we find very similar results across different debates. Overall, our analysis lends support to the argument that politicians use emotive rhetoric strategically in parliamentary debates to appeal to a wider audience.

Our article thus makes three main contributions. First, by analyzing how politicians use emotive rhetoric in parliaments, we contribute to the understanding of political competition. Most previous work on parliamentary speeches emphasizes the role of ideological positions and the expression of dissent (Baumann, Debus, and Klingelhöfer 2017; Herzog and Benoit 2015; Proksch et al. 2019; Slapin et al. 2018). While these features are central to our understanding of political speeches, we argue that the "tone" and emotiveness of speeches should also be considered. Our article thus extends previous work on the role of emotions in political rhetoric, both in the UK (Crines 2013; Finlayson and Martin 2008; Prior 2018) and in the field of international relations (Holmes 2015; Koschut et al. 2017). Second, our paper contributes to the study of legislative behavior by emphasizing how the incentives of politicians differ across types of debates. Previous work suggests that parliamentarians use parliamentary speeches strategically to appeal to voters (Maltzman and Sigelman 1996; Proksch and Slapin 2012; Rheault et al. 2016; Spirling 2016). Our research provides evidence that the incentives to appeal to voters differ systematically across different types of debates. Finally, we present a novel methodological application to measure emotive rhetoric by combining the well-established ANEW dictionary with word-embedding techniques. Here we build upon existing work, which shows that wordembedding techniques can improve the performance of dictionaries (Rice and Zorn 2019).

\footnotetext{
${ }^{1}$ While devolution has transferred significant powers to legislatures in Scotland, Wales, and Northern Ireland, the UK Parliament still holds ultimate parliamentary sovereignty (see Appendix A).
}

\section{EMOTIVE POLITICAL RHETORIC}

Speeches are a crucial tool for communicating political messages. Politicians frequently transmit their viewpoints to the wider public through speeches, generally via the media, ranging from TV to social media platforms (Aalberg and Curran 2012; Ponder and Haridakis 2015). Any political message includes two core components: first, the "focus" or the position through which the speaker targets their audience, and second, the tone expressed in the message (e.g., Jung 2020).

Most research on parliamentary speeches has focused on the first part (e.g., Baumann, Debus, and Klingelhöfer 2017; Herzog and Benoit 2015; Martin and Vanberg 2008; Proksch and Slapin 2012; Proksch et al. 2019; Slapin et al. 2018). For example, Slapin et al. (2018) examine legislative speeches in the United Kingdom and argue that rebel parliamentarians from government parties strategically deviate from the party leadership to signal their preferred policy stance to their electorate. Opposition parliamentarians are likely to benefit less from this strategy, because they may be perceived as supporting the government. Other studies have shown that the political ambition of legislators affects the way they behave in parliament. Politicians who seek higher office have electoral incentives to act in ways that appeal to a larger electorate (Hibbing 1986) and to be more responsive to public opinion (Høyland, Hobolt, and Hix 2019; Victor 2011). Such attempts to appeal to the electorate are evidenced in patterns of legislative voting. While there is a growing interest in parliamentary speeches (Blumenau 2021; Proksch and Slapin 2012; Spirling 2016), less attention has been paid to the emotional content of the speeches (for exceptions, see, e.g., Rheault et al. 2016; Slapin and Kirkland 2020). ${ }^{2}$

However, research in political behavior suggests that appeals to emotions can significantly influence voters. For example, recent work demonstrates that emotive appeals can increase participation and activate existing loyalties (Brader 2005), mobilize populist support (Wirz 2018), affect the way information is interpreted (Weeks 2015), and change public opinion (Kühne et al. 2011). Qualitative research also highlights the importance of studying emotive rhetoric in order to understand the behavior of politicians and their interaction with voters (Prior 2018; Prior and van Hoef 2018).

Bridging these two strands of literature, on parliamentary speeches and on the role of emotive rhetoric in politics, we develop an argument for why politicians use emotive appeals in their speeches for strategic reasons.

\section{Emotions and Political Persuasion}

Emotive or "loaded" language generally refers to a style of communication that elicits an emotional response from the listener, thereby evoking positive or negative reactions that go beyond the specific

\footnotetext{
${ }^{2}$ Slapin and Kirkland (2020) find no robust statistical relationship between rebel parliamentarians and positive or negative language.
} 
meaning of the word or sentence used. Linguists have identified that emotions are built-in devices of human expressiveness and that the expression of verbal emotions allows listeners to get information about the speakers' interpretation of their message (e.g., Damasio 2000; Macagno and Walton 2014). In other words, some prosodic cues - certain words, pitch, stress, etc. - inform individuals that speakers are using emotive language, which they will subsequently use to interpret the content of the message (Bull 2002; Gerholm 2018).

Emotive language can be a powerful tool for persuading people of the validity of a particular message. For instance, experimental research has shown that individuals who feel happy are more likely to be persuaded, independent of the strength of the argument (Bless, Mackie, and Schwarz 1992; Griskevicius, Shiota, and Neufeld 2010; Sinclair, Mark, and Clore 1994). The effect of emotive language appears to be present even when the speech is solely transmitted in a written format (Heath 2017; Yeung 2007). Political psychologists often argue that "politics is about feeling" (Redlawsk 2006) as much as it is about thinking (Redlawsk and Pierce 2017). Indeed, previous works have pointed out that people often use emotional expressions to convince others and to send a signal of their own attitude toward a topic (Rocklage, Rucker, and Nordgren 2018; Van Kleef, van den Berg, and Heerdink 2015). Formal theorists have argued that emotions can motivate citizens to abandon individual rational utility calculation and engage in politics (Groenendyk 2011). Emotive rhetoric has also been linked to the quality of political deliberation (Steiner et al. 2005).

From an electoral competition point of view, there is evidence linking emotion-eliciting appeals with the electoral success of certain political formations, such as populist parties (Wirz 2018). Emotion shapes how citizens respond to misinformation (Weeks 2015) and represents an important component in understanding campaign effects (Weber 2013). Studies on rhetorical political analysis have examined the use of emotions in the rhetorical performance of UK parliamentarians (Atkins et al. 2014; Crines 2013; Crines, Heppell, and Hill 2016; Finlayson and Martin 2008). For instance, Crines and Heppell (2017), building on an analysis of speeches of the leader of the United Kingdom Independence Party (UKIP), conclude that Nigel Farage often relies on emotional appeals, such as hyperbole and fear, in order to define his position on identity issues. Similarly, Prior (2018) suggests that emotions are an important tool employed by parliamentarians in their "engaging storytelling" strategy to effectively communicate with voters.

Even though the debate on whether emotions increase or decrease political mobilization is still ongoing (Brader 2005; Ryan 2012; Valentino et al. 2008), the important point from a politician's point of view is that emotional appeals can affect an individual's political attitudes and political behavior (Renshon, Lee, and Tingley 2015). To mention a few examples, when politicians use emotive language, party identification increases (Groenendyk and Banks 2014), individuals are more likely to be persuaded (Arceneaux
2012), and they are more likely to resort to affective heuristics when making decisions (Kühne et al. 2011). Considering this evidence, we would also expect that politicians use emotional language strategically to appeal to voters.

\section{Strategic Incentives and Audience Exposure}

Given the importance of emotional appeals to voters, this paper focuses on the emotive language in legislative speeches. We argue that emotional appeals are one of the tools that politicians can use to appeal to voters, in addition to other well-studied aspects of political messages, such as ideological positioning and agenda setting. Building on a rational choice approach (Downs 1957), politicians are regarded as strategic agents who seek to maximize their electoral appeal. Thus, we contend that they will be more likely to resort to emotive language when they think they can obtain positive electoral rewards. Legislative speeches are used for multiple purposes, including conveying information to other parliamentarians and signaling competence to party leaders.

Our core argument is that legislators will strategically employ more emotive language to convey their messages when they expect that more voters are likely to hear their speeches and thus more likely to respond to their appeals. This argument builds upon recent research, which shows that elites' rhetoric changes in response to voter incentives. Previous research provides evidence that politicians adapt the comprehensibility of their speeches to their constituents' linguistic skills to facilitate effective communication (Lin and Osnabrügge 2018; Slapin and Kirkland 2020; Spirling 2016). For example, ministers of the UK became significantly easier to understand, relative to backbenchers, immediately after the 1868 election, when the electorate doubled with the incorporation of mostly poorer and less educated voters (Spirling 2016). Hager and Hilbig (2020) find that sudden exposure to public opinion leads elites to align their language - the tone and the content of their discourse - to that of the public opinion. Bryan and Ringsmuth (2016) show that dissenting judges in the Supreme Court use more emotive language to attract the public's attention, influence the public debate on the issue, and provoke further litigation.

Importantly, it is not always advantageous for legislators to use emotive language-otherwise they would be using emotive rhetoric all the time. While emotiveness has been shown to attract the attention of voters, such language can also signal a lack of credibility, seriousness, and expert knowledge in other contexts. For example, research on the language that lawyers use has shown that overtly emotional rhetoric suggests that the lawyer using it lacks credibility. Conversely, a legal statement that contains objective and logical information highlights the credibility and expertise of the writer (Black et al. 2016; Scalia and Garner 2008). Therefore, parliamentarians seeking to persuade their audience have to balance ethos (ethical appeals), logos (logical appeals), and pathos (emotional appeals). The chosen rhetoric, we argue, will depend on the audience. In legislative debates with a larger electoral audience 
(e.g., via media attention), politicians have greater incentives to employ more emotional appeals, whereas in debates that are focused primarily on persuading other parliamentarians and party leaders of their expertise and credibility, they are incentivized to use more neutral and technical language. Of course, politicians can use emotive rhetoric in any parliamentary debate or speech in the hope that it will help them attract the attention of their constituents. However, high-profile debates are particularly convenient platforms for politicians to leverage to appeal to voters because such debates are followed more closely by the media (Salmond 2014). We therefore anticipate that the level of emotive rhetoric differs across types of debates, depending on the size of the electoral audience.

In most parliaments, such as the House of Commons, the electoral audience argument is first and foremost evident by observing the type of the debates that members of parliament (MPs) participate in. While some debates are very low-profile events, others generate considerable public and media interest. Most notably, there is one very high-profile weekly debate in the House of Commons - namely, PMQs, which is a convention during which the prime minister answers questions from MPs, particularly from the Leader of the Opposition. It is the most prominent parliamentary moment of the week, broadcast live and extensively covered by the media. PMQs is arguably the debate citizens are more likely to be exposed to, thus providing incentives to MPs to use more emotive language in their PMQs speeches than in other legislative debates. The same argument applies to other high-profile debates in other parliamentary systems, such as Leaders' Questions in Ireland. Such high-profile debates receive greater attention by both voters and the media, thereby increasing the potential audience that messages are transmitted to and representing an important opportunity for legislators to appeal to voters by using emotive language. This leads to our main hypothesis:

$H$ : Legislators make greater use of emotive rhetoric in high-profile debates than in low-profile debates.

We examine this hypothesis by analyzing House of Commons debates between 2001 and 2019. This allows us to examine the rich variation in legislative speeches, both in terms of emotive content of the speeches and the exposure of the speakers to a larger or smaller audience. We also test our expectations using data from the lower house of the Irish Parliament between 2002 and 2013. Below we discuss the nature and type of legislative debates in the House of Commons in more detail.

\section{DEBATES IN THE HOUSE OF COMMONS}

In this section, we consider the nature of debates in the House of Commons and the attention they attract. The term debate refers to "a sequence of utterances pertaining to the same subject at a particular time as demarcated by parliamentary recorders" (Eggers and
Spirling 2014, 877). ${ }^{3}$ The lower house of the Parliament of the United Kingdom, formally known as The House of Commons of the United Kingdom of Great Britain and Northern Ireland, hosts different types of debates (Norton 2013). Our analysis focuses on PMQs and Ministerial Question Times, Queen's Speech debates, and Urgent Questions.

An important type of debate are question times, which take place from Monday to Thursday (House of Commons 2019, Standing Order 21). Questions to the Prime Minister takes place on a weekly basis, usually each Wednesday ${ }^{4}$, and departmental ministers follow the rotation principle. During PMQs, the Prime Minister answers questions from opposition leaders and backbenchers. The Leader of the Opposition has a guaranteed number of questions and is permitted to ask six questions (Bates et al. 2014; Bates, Kerr, and Serban 2018). To ask a question, parliamentarians need to submit a question to the Table Office, which selects the questions randomly (Hutton et al. 2019). The Prime Minister attends question time on a weekly basis and the departmental ministers typically answer questions every five weeks. Ministerial Question Time ends with topical questions, which are open questions.

A second prominent debate is the Queen's Speech debate, which occurs at the beginning of a new parliamentary session. In the Queen's Speech, the Queen reads the main legislative priorities of the government. Afterwards, a mover and seconder move the debate on the Address in reply in the House of Commons. The debate on the Address has three parts. In the first part, parliament debates the main government policies in a general manner. This takes place on the opening day and focuses on the entire government policy. The Leader of the Opposition and the Prime Minister usually take part in this debate. The second part of the debate focuses on specific policy areas. Last, the debate includes amendments on the Address. In total, the debate on the Queen's Speech takes five to six days (Hutton et al. 2019, chaps. 8, 18).

Urgent Questions are another format in the House of Commons (Martin and Rozenberg 2012). Parliamentarians can submit each day for an urgent question to the Speaker. If the Speaker considers the matter to be urgent and important, the parliamentarian can ask the question after the question time or on Friday at 11 a.m. The government can decide which minister responds to the urgent question (Hutton et al. 2019, chap. 19).

These debates in the House of Commons differ significantly with respect to the expected audience.

\footnotetext{
${ }^{3}$ Note that the parliamentary procedures of the House of Commons distinguish between debates and questions (Hutton et al. 2019; Norton 2013). We follow existing literature and use the term debate to refer to both of these settings (e.g., Bäck, Debus, and Fernandes Forthcoming; Blumenau and Damiani Forthcoming).

${ }^{4}$ Since the 1960s, PMQs were a twice-weekly session of 15-minutes. In 1997, Prime Minister Tony Blair replaced them with a single 30-minute session. In addition, the allocated number of questions in each session for the Leader of the Opposition was doubled from three to six.
} 
PMQs are the most high-profile debates. They are broadcast live on TV and the radio and receive extensive media coverage: TV snippets of the debate are featured in the media, usually during the daily news programs (Betsy and Goldsmith 2019; Salmond 2014). According to Bates, Kerr, and Serban (2018, 8), PMQs "provide a high-profile means for MPs to maintain Parliament's representational link between government and citizens." The British public is generally familiar with PMQs and the head-to-head debate between the Prime Minister and the Leader of the Opposition (Norton 2013, 122-123). Indeed, data from YouGov/The Hansard Society Survey results shows that almost $70 \%$ of the population either regularly watches the PMQs or have seen it. ${ }^{5}$ Appendix C illustrates further evidence suggesting that PMQs receive a relatively high level of attention.

In contrast to PMQs, the Ministerial Question Times receive less attention and "are characterized at times by informed questioning by a small number of members pursuing issues of concern to constituents and others in society" (Norton 2013, 123). In the Queen's Speech debate, the opening day including the exchange between the Prime Minister and the Leader of the Opposition receives a high level of attention, but the other days receive less attention in the public debate. The size of the audience of Urgent Questions is less predictable because the questions are submitted on the same day (Bates, Kerr, and Serban 2018).

We thus leverage the variation in the visibility of the different debates to examine whether the level of emotive rhetoric of MPs varies accordingly.

\section{DATA}

To test variation in emotive rhetoric across individual speakers and debates, we build a dataset on all parliamentary speeches held in the House of Commons in the period from 2001 until 2019 (Osnabrügge, Hobolt, and Rodon 2021). We use the data from Rheault et al. (2016) for the period from 2001 until 2014 and extend this dataset until 2019 using information from TheyWorkForYou ${ }^{6}$. We drop speeches with less than 40 characters because these oral contributions are either interruptions or very brief statements and, because our study focuses on the strategic incentives of politicians, we also remove speeches by the Speaker or the Deputy Speakers of the House of Commons (Peterson and Spirling 2018).

In addition, we extract from the Hansard and TheyWorkForYou detailed meta-data on the type of speech. We create a set of indicators equal to one if a speech is held in a particular debate, and zero otherwise. More precisely, we generate indicator variables for PMQs, Queen's Speech debates (opening day and other days), Ministerial Question Times, Urgent Questions, and speeches held in other debates. The indicator variable

\footnotetext{
${ }^{5}$ Data were collected in September 2015. Source: YouGov (last accessed on August 27, 2019).

${ }^{6}$ Source: TheyWorkForYou (last accessed on July 22, 2019).
}

on PMQs is our main explanatory variable. We use the other debates as a reference category.

We complement the dataset by incorporating MPs' individual characteristics. These controls are important because parliamentarians with specific features or in certain roles might be more emotive and more likely to participate in high-profile debates. Additionally, some MPs' characteristics might be correlated with the use of emotive language. To be more specific, we add information on the party, party leadership position, ministerial position, shadow cabinet, seniority, committee chairmanship, gender, and age. Minister is a binary variable that captures whether an MP is a ministersenior and junior-or not. Shadow cabinet is an indicator variable equal to one if a parliamentarian is the Leader of the Opposition, the shadow Deputy Leader, the shadow Chancellor of the Exchequer, or the shadow Secretary of State for Foreign and Commonwealth Affairs. Seniority is coded as one if the MP is the Secretary of State for the Home Department, the Secretary of State for Foreign and Commonwealth Affairs, or the Chancellor of the Exchequer, and zero otherwise. Committee chairmanship is also an indicator variable equal to one if a parliamentarian is a committee chair, and zero otherwise. Gender is an indicator variable equal to one if a parliamentarian is a woman, and zero otherwise. The party indicator is a categorical variable that distinguishes between the different parties in the House of Commons. We use information from the House of Commons to compile the individual-level data.

Table 1 summarizes our data on parliamentary speeches, which encompasses 958,925 speeches from five electoral periods. A total of 34,030 speeches were held in the PMQs and 15,160 in the Queen's Speech debates, 279,076 in Ministerial Question Times, and 37,523 in Urgent Questions. Appendix D includes further descriptive information.

\section{MEASURING EMOTIVE RHETORIC}

Two main approaches can be used for measuring emotive rhetoric (Grimmer and Stewart 2013): First, supervised learning, which involves hand-annotating a subset of the speeches according to their level of emotiveness and training a machine learning algorithm on the handannotated data to predict the labels of unseen speeches. Second, researchers can use dictionary-based methods. We adopted a dictionary-based approach because the generation of a training data on emotive rhetoric using human annotators is very costly. Specifically, we combine the Affective Norms for English Words (ANEW) with word-embedding techniques to create a domainspecific dictionary. ${ }^{8}$ The ANEW dictionary allows us to produce an exogenous measure of emotive rhetoric

\footnotetext{
${ }^{7}$ https://researchbriefings.parliament.uk/ResearchBriefing/Sum mary/CBP-8256 (last accessed on February 22, 2020).

${ }^{8}$ An alternative approach would be to measure emotive rhetoric based on visual or audio data (Dietrich, Hayes, and O'Brien 2019).
} 
TABLE 1. Data on Speeches in the House of Commons

\begin{tabular}{lccccc}
\hline Period & Number of speeches & PMQs & $\begin{array}{c}\text { Queen's Speech } \\
\text { debates }\end{array}$ & $\begin{array}{c}\text { Ministerial } \\
\text { Question Time }\end{array}$ & Urgent Questions \\
\hline $2001-2005$ & 171,686 & 6,398 & 3,159 & 45,818 & 1,337 \\
$2005-2010$ & 227,467 & 8,301 & 4,297 & 64,910 & 1,653 \\
$2010-2015$ & 285,760 & 9,730 & 3,914 & 85,280 & 9,856 \\
$2015-2017$ & 116,287 & 3,786 & 1,709 & 35,084 & 7,696 \\
$2017-2019$ & 157,725 & 5,815 & 2,081 & 47,984 & 16,981 \\
Total & 958,925 & 34,030 & 15,160 & 279,076 & 37,523 \\
\hline
\end{tabular}

that is not contaminated by partisan attitudes and political predispositions. However, as all generic dictionaries, the ANEW dictionary was not developed for political texts, which may produce measurement error (Grimmer and Stewart 2013, 275). To address this problem, we use word-embedding techniques (Gennaro and Ash 2021; Rice and Zorn 2019), and add context-specific words to the dictionary. The main advantage of this method over manually adding words is that it is more transparent and systematic. In contrast to the work on sentiment analysis, we do not study whether politicians use positive or negative language (Proksch et al. 2019; Young and Soroka 2012); we focus on emotional appeals versus neutral language. However, in Appendix $\mathrm{F}$ we show that our results are robust if we distinguish between positive and negative affect, as high-profile debates include both more positive and more negative language.

Using the ANEW dictionary comes with several advantages. First, the methodology for creating the ratings has been validated and the dictionary is wellestablished in the scientific community (Bradley and Lang 2017). Second, the dictionary is freely available, which facilitates replication. Third, the ANEW dictionary includes complete words (rather than stemmed words) and emotive as well as neutral words, which facilitates the application of word-embedding techniques.

We create the domain-specific dictionary in several steps. First, we identify seed words in the ANEW dictionary. We define neutral words as words that are associated with neither positive nor negative emotions. The ANEW dictionary includes 851 emotive words and 970 neutral words. We do not consider words that have a rating with a large standard deviation because we are interested in words that are unambiguously emotive and neutral. ${ }^{9}$ We change the spelling of several words from American English to British English.

\footnotetext{
${ }^{9}$ In the ANEW dictionary, a score of 1 means that a word is very negative/unpleasant/unhappy and a score of 9 refers to very positive/ pleasant/happy words. Emotive words have a score below 3 and above 7 and neutral words have a score above 4 and below 6 . We focus on words with a standard deviation lower than 2 to make sure these words are unambiguously emotive or neutral. We removed words from the ANEW dictionary that are not used in parliamentary speeches and, thus, are not in our vocabulary. Furthermore, we remove stopwords and the word "friend" from our list of seed words
}

Second, we estimate the word vectors based on our corpus of parliamentary speeches using the skip-gram model with hierarchical softmax as implemented in the gensim python module (Mikolov, Chen, et al. 2013; Mikolov, Sutskever, et al. 2013; Řehůřek and Sojka 2010). For the computation of word vectors, we split the speeches into randomly ordered sentences ${ }^{10}$ (Rheault and Cochrane 2020). In our main analysis, we use word embeddings calculated based on a window of 10 words and a vector dimensionality of $250 .{ }^{11}$ These word vectors capture the word meaning.

Third, we calculate an emotive score for each vocabulary word that is not a seed word by comparing its word vector with the word vectors of the seed words. For each word, we add the cosine similarities between the word and the emotive seed words and then subtract the cosine similarities between the word and the neutral seed words (Rheault et al. 2016; Turney and Littman 2003).

$$
s_{i}=\sum_{e=1}^{E} \frac{\mathbf{v}_{i} \cdot \mathbf{v}_{e}}{\left\|\mathbf{v}_{i}\right\|\left\|\mathbf{v}_{e}\right\|}-\sum_{n=1}^{N} \frac{\mathbf{v}_{i} \cdot \mathbf{v}_{n}}{\left\|\mathbf{v}_{i}\right\|\left\|\mathbf{v}_{n}\right\|}
$$

The words in our vocabulary that are not seed words are indexed $i$, the emotive words are indexed $e=1, \ldots, E$, and $n=1, \ldots, N$ refers to the neutral phrases.

Figure 1 illustrates the score of the words with the highest and lowest level of emotiveness. Words with a high emotive loading are appalling, empathy, horrific, and admiration. Neutral words include words such as walkway, diameter, metres, and radiators. These words are not in the ANEW dictionary, but our word embeddings suggest that these words are highly related to our emotive and neutral seed words, respectively.

We identify for each pole the words with the highest and the lowest score and add these words to the dictionary. ${ }^{12}$ This procedure leads to a vocabulary of 2,015 emotive and 2,095 neutral words. We compute the level

because the term "My Right Honourable Friend" is frequently used as a form of address in the House of Commons.

${ }^{10}$ We remove stopwords and two-letter words and sentences with only one word and focus on all words that appear at least eight times in the corpus. We do not lemmatize or stem the words.

${ }^{11} \mathrm{We}$ also implement multiple robustness tests (Rodriguez and Spirling Forthcoming). For example, we examine the robustness by running the analysis with an eight-word window and a dimensionality of 300. The main results are robust. Appendix F shows these results ${ }^{12} \mathrm{We}$ add words above the 0.975 and under the 0.025 quantiles. 
FIGURE 1. Word Clouds of Emotive and Neutral Words

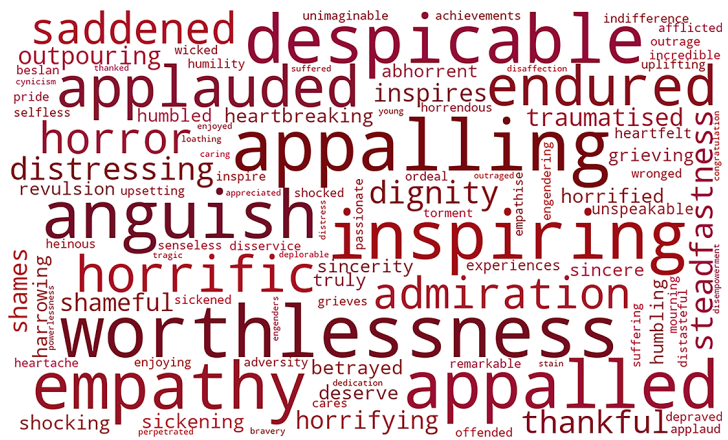

(a) Emotive

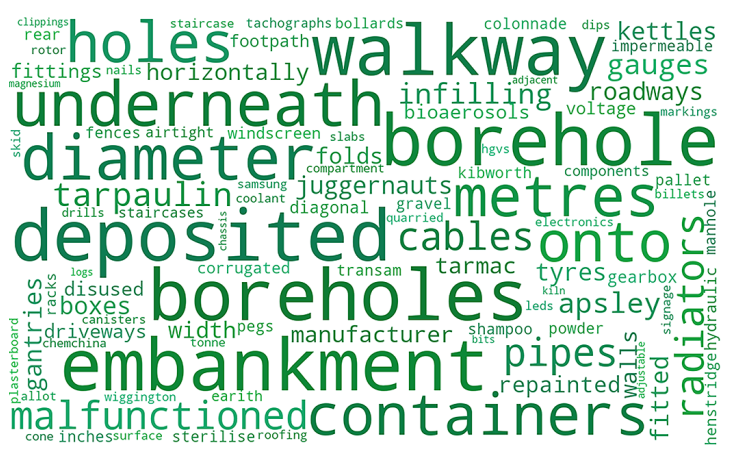

(b) Neutral

\section{TABLE 2. Examples: Emotive and Neutral Speeches}

\begin{tabular}{|c|c|c|}
\hline Score & Text & Speaker \\
\hline 43 & $\begin{array}{l}\text { Evil happens when good people stand by and do nothing. There is evil running through and } \\
\text { infiltrating the Labour party, but it is full of good people and they are trying to do something } \\
\text { about it. I commend them, appreciate them and have nothing but respect for them. }\end{array}$ & $\begin{array}{l}\text { Alec Shelbrooke, } \\
\text { MP }\end{array}$ \\
\hline-25 & $\begin{array}{l}\text { When used with old-fashioned copper wires, } 10 \text { megabits can become a lot less than that. } \\
\text { We need a superfast fibre infrastructure instead of copper wires. }\end{array}$ & $\begin{array}{l}\text { Geoffrey Clifton- } \\
\text { Brown, MP }\end{array}$ \\
\hline
\end{tabular}

of emotive rhetoric by subtracting the percentage of neutral from the percentage of emotive words (Bird, Klein, and Loper 2009). The scale is thus from $-100 \%$ to $+100 \%$. The average level of emotive rhetoric is 0.88 and the standard deviation is equal to 8.95. This suggests that most words in a parliamentary speech are neither highly emotive nor highly neutral. We provide further information on the distribution in Appendix D. Table 2 demonstrates a speech with high and a speech with low levels of emotive rhetoric.

\section{RESULTS}

In this section, we start by examining the level of emotive rhetoric graphically. Thereafter we present the results of regression models to analyze the relationship between the type of debate and the level of emotiveness at the speech level. When interpreting the effect sizes, it is important to keep in mind that even a small number of emotive words can strongly influence the rhetorical style or meaning of a speech (see e.g., Crabtree et al. 2020; Eichorst and Lin 2019).

Figure 2 illustrates the development of emotive rhetoric in the period 2001 until 2019. As discussed, the scale is from $-100 \%$ to $100 \%$. The figure shows that the variation in emotive rhetoric is substantial across all debate forms. We distinguish between speeches held in the PMQs, Queen's Speech debates (opening day and other days), Ministerial Question Times, Urgent Questions, and other debates. Each dot represents the average level of emotive rhetoric in a half-year by different types of debates. To provide contextual reference points, the two dotted vertical lines correspond to the beginning of the Iraq war and the Brexit referendum two highly polarizing and emotive issues in the UK Parliament. The figure illustrates that the level of emotive rhetoric is highest for PMQs and the opening day of the Queen's Speech debate, in line with our expectation.

The comparison of PMQs and Ministerial Question Times suggest that the high level of emotive rhetoric in PMQs is not the result of the "question time" format. The level of emotive rhetoric of ministerial questions is lower than in PMQs. The Urgent Questions exhibit large variation in early years because the number of Urgent Questions was relatively low. The level of emotive rhetoric also varies over time. The figure illustrates that the level of emotive rhetoric appears to increase in the period when the Iraq war began. We also observe increasing trends before the Brexit referendum and before the UK left the European Union. The other debates, such as Queen's Speech debate, also become more emotive over time, but the trend is less strong for other days of the Queen's Speech debate, Urgent Questions, and the Ministerial Question Time. The level of emotive rhetoric in Urgent Questions exhibits significant variation, especially in the period before $2009 .{ }^{13}$ Overall, this shows that in line with our

\footnotetext{
${ }^{13}$ One reason for this variation is that the number of Urgent Questions was very low in early years and then substantially increased after John Bercow became Speaker of the House of Commons in 2009 (Blumenau and Damiani Forthcoming).
} 


\section{FIGURE 2. Emotive Rhetoric by Type of Debate over Time}

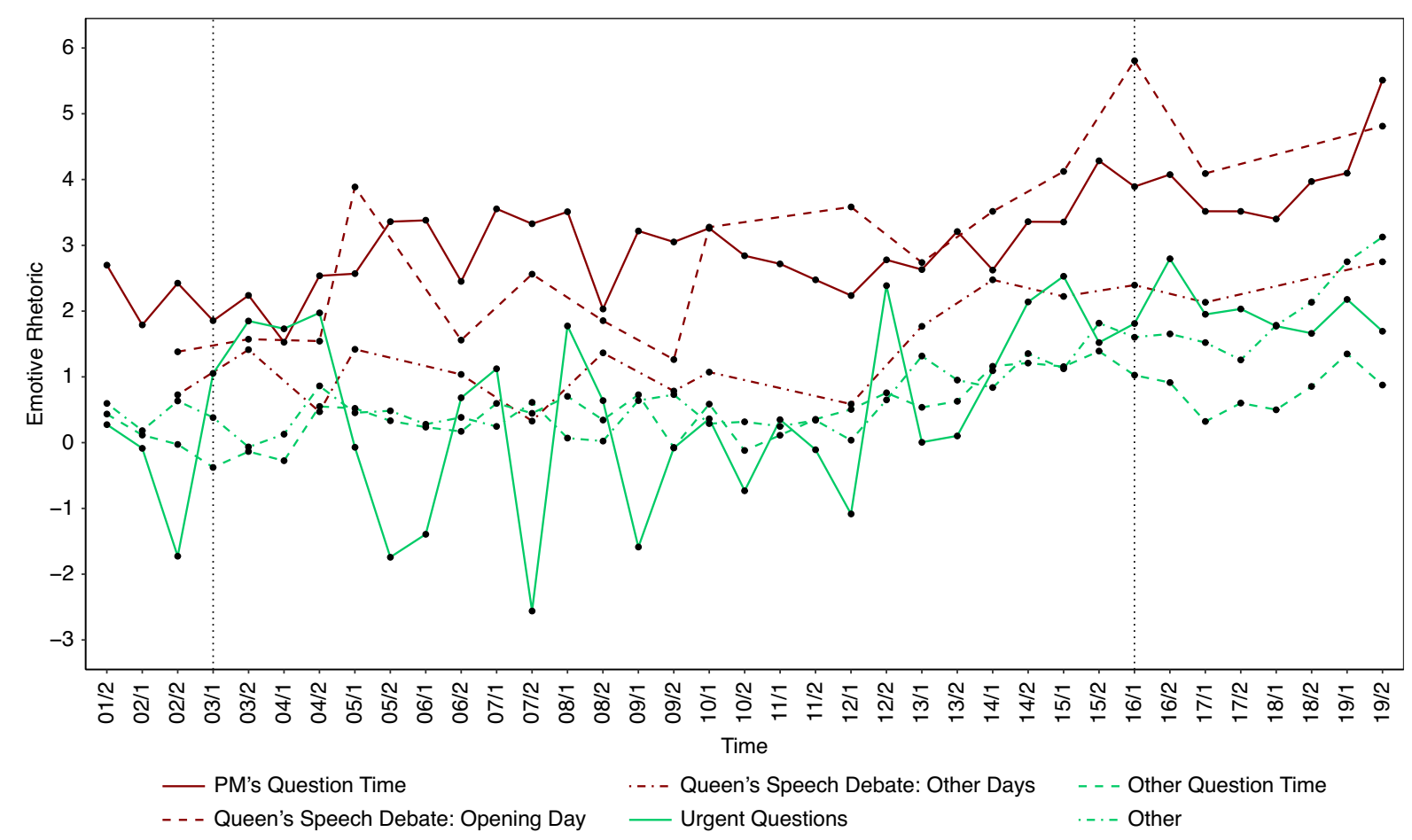

Note: The figure summarizes the average level of emotive rhetoric for half-year periods.

expectations, the high-profile debates that attract a larger audience and greater media coverage are also those in which MPs employ more emotive rhetoric.

As a next step in the analysis, we use linear regression to examine the association between debate type and emotive rhetoric. Table 3 summarizes our main results. We run five regression models with different specifications. In all models, the standard errors are clustered at the MP level. Appendix E includes the full regression output.

Model 1 is a baseline model, which includes our explanatory variables, which capture the type of debate in which the speech is given. The results show that the effects of the variables capturing PMQs and Queen's Speech debates (opening day and other days) are statistically significant at the 0.01 level. More concretely, we observe that if a speech is held during PMQs, the percentage point difference between emotive and neutral words increases by 2.2. If we compare the effect across the type of debates, we observe that the effect size of the PMQs and the opening day of the Queen's Speech debates is the largest, followed by the effect of the other days of Queen's Speech debates. The effect of Ministerial Question Times is negative, but the effect size is relatively small. The effect of Urgent Questions is not robust.

Model 2 includes our main explanatory variables and a linear time trend. The effects of PMQs and Queen's Speech debates are robust and the coefficient sizes are very similar, as in Model 1. In Model 3, we include a linear time trend and speaker fixed effects. MP fixed effects allow us to study the within-MP variation over time. The MP-specific fixed effects correct for all timeconstant heterogeneity among parliamentarians. As the table shows, the coefficients for PMQs and Queen's Speech debates are very similar to those from the previous models. The evidence suggests that the high level of emotive rhetoric in PMQs is not the result of different speaker characteristics.

The inspection of the rules of debate supports this conclusion. In particular, except for the Leader of the Opposition, no parliamentarian receives priority in speaking in PMQs. ${ }^{14}$ Importantly, the questions for PMQs are selected randomly from all the parliamentarians that expressed interest in asking a question, so this reduces the potential problem of selection bias in who speaks (Betsy and Goldsmith 2019; Kelly 2015).

In Model 4 we include a linear time trend, party fixed effects, and controls for party leader position, gender, ministerial position, shadow cabinet, committee chairmanship, party, and age. We include the controls because certain parliamentarians might be more likely to be emotive and participate in PMQs. We find that the effect of the type of debate is robust and is similar in size to those of the previous models. The results for the control variables show that party leaders are more likely to use emotive rhetoric. In addition, we also find

\footnotetext{
14 The leader of the second largest opposition party can ask two questions.
} 
TABLE 3. Regression Analysis of Emotive Rhetoric

\begin{tabular}{|c|c|c|c|c|c|}
\hline & (1) & (2) & (3) & (4) & (5) \\
\hline PMQs & $\begin{array}{l}2.226^{\star \star} \\
(0.128)\end{array}$ & $\begin{array}{l}2.198^{\star *} \\
(0.124)\end{array}$ & $\begin{array}{l}1.562^{\star *} \\
(0.137)\end{array}$ & $\begin{array}{l}1.618^{\star *} \\
(0.167)\end{array}$ & $\begin{array}{l}1.663^{* *} \\
(0.214)\end{array}$ \\
\hline Queen's Speech Debate: Opening Day & $\begin{array}{l}2.172^{\star *} \\
(0.214)\end{array}$ & $\begin{array}{l}2.166^{\star \star} \\
(0.208)\end{array}$ & $\begin{array}{l}1.943^{\star \star} \\
(0.180)\end{array}$ & $\begin{array}{l}2.061^{* \star} \\
(0.194)\end{array}$ & $\begin{array}{l}2.064^{\star \star} \\
(0.166)\end{array}$ \\
\hline Queen's Speech Debate: Other Days & $\begin{array}{l}0.581^{\star *} \\
(0.106)\end{array}$ & $\begin{array}{l}0.623^{\star \star} \\
(0.104)\end{array}$ & $\begin{array}{l}0.515^{\star \star} \\
(0.083)\end{array}$ & $\begin{array}{l}0.643^{\star *} \\
(0.095)\end{array}$ & $\begin{array}{l}1.090^{\star \star} \\
(0.078)\end{array}$ \\
\hline Ministerial Question Time & $\begin{array}{l}-0.293^{\star \star} \\
(0.074)\end{array}$ & $\begin{array}{c}-0.354^{* *} \\
(0.072)\end{array}$ & $\begin{array}{c}-0.433^{\star *} \\
(0.053)\end{array}$ & $\begin{array}{c}-0.378^{\star *} \\
(0.069)\end{array}$ & $\begin{array}{l}-0.207^{*} \\
(0.057)\end{array}$ \\
\hline Urgent Questions & $\begin{array}{l}0.610^{\star \star} \\
(0.116)\end{array}$ & $\begin{array}{l}0.148 \\
(0.105)\end{array}$ & $\begin{array}{c}0.009 \\
(0.089)\end{array}$ & $\begin{array}{c}0.162 \\
(0.099)\end{array}$ & $\begin{array}{l}0.044 \\
(0.096)\end{array}$ \\
\hline Constant & $\begin{array}{l}0.850^{\star \star} \\
(0.072)\end{array}$ & $\begin{array}{l}-0.075 \\
(0.101)\end{array}$ & $\begin{array}{c}0.033 \\
(0.082)\end{array}$ & $\begin{array}{c}-1.664^{* *} \\
(0.361)\end{array}$ & $\begin{array}{l}0.188^{*} \\
(0.080)\end{array}$ \\
\hline $\begin{array}{l}\text { Linear time trend } \\
\text { MP fixed effects }\end{array}$ & & $x$ & $\begin{array}{l}\mathrm{X} \\
\mathrm{X}\end{array}$ & $\mathrm{x}$ & $\begin{array}{l}X \\
X\end{array}$ \\
\hline Controls & & & & $\mathrm{X}$ & \\
\hline Weighting by speech length & & & & & $\mathrm{x}$ \\
\hline $\begin{array}{l}N \\
R^{2}\end{array}$ & $\begin{array}{l}958,925 \\
0.003\end{array}$ & $\begin{array}{l}958,925 \\
0.006\end{array}$ & $\begin{array}{l}958,925 \\
0.041\end{array}$ & $\begin{array}{l}958,925 \\
0.014\end{array}$ & $\begin{array}{c}958,925 \\
0.094\end{array}$ \\
\hline
\end{tabular}

\section{FIGURE 3. Predicted Level of Emotive Rhetoric by Type of Debate and $95 \%$ Confidence Intervals}

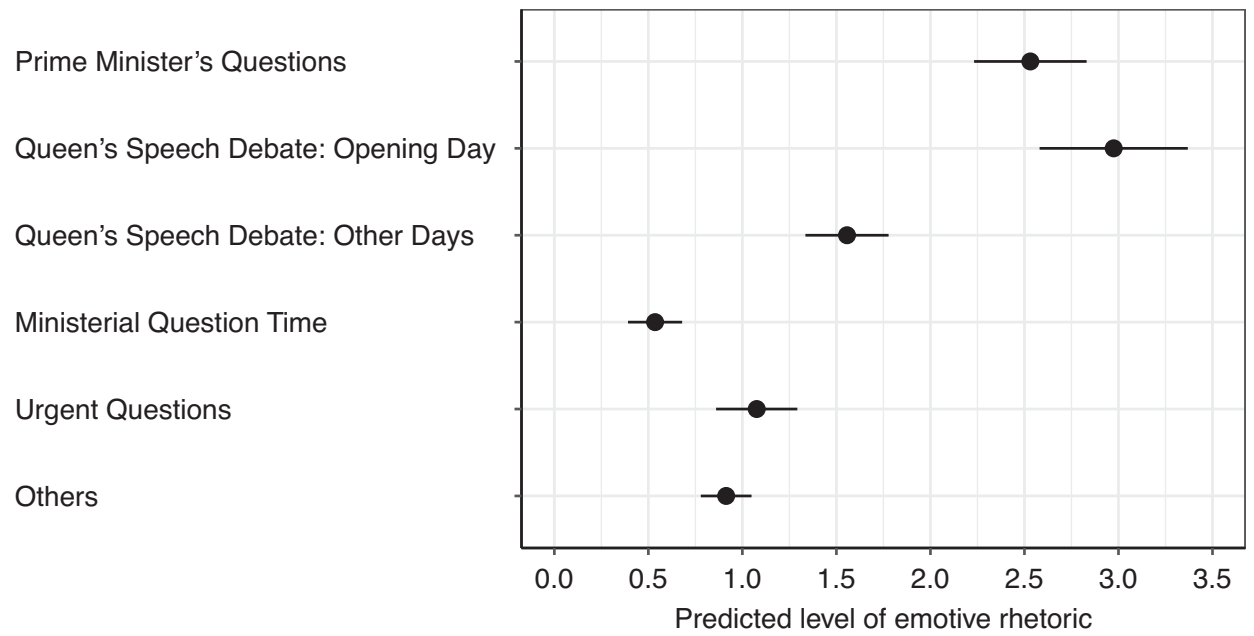

Note: The predictions are predictive margins computed based on Model 4.

that women MPs tend to use more emotive rhetoric than men MPs. ${ }^{15}$

In Model 5, we run our regression analysis with a linear time trend and MP fixed effects and weight the speeches by their length to account for the different number of words. As the table illustrates, the effect of the type of debates is robust and similar to that from the other models. Note that the effects are also robust if we control for the number of words.

\footnotetext{
$\overline{15}$ Appendix $\mathrm{G}$ presents further analyses using alternative measures and models. Appendix $\mathrm{J}$ examines the role of gender in our models.
}

Using Model 4 as reference, we calculate the predicted levels of emotive rhetoric for speeches held in different debates. We show the results in Figure 3. The predicted level of emotive rhetoric in speeches held during PMQs and the opening day of the Queen's Speech debate is around 2.5 and 3.0, respectively. In other words, the predicted percentage of emotive words minus the percentage of neutral words is 2.5 3.0. The predicted level of emotive rhetoric in other days of the Queen's Speech debates equals 1.5. The model also predicts that the level of emotive rhetoric in Ministerial Question Time, Urgent Questions, and other debates is 1.0 or lower. This means that the level 
of emotive rhetoric in other debates is less than half of that in PMQs and Queen's Speech debates.

We also explore the effect of electoral cycles and do find an effect of electoral cycles on emotive rhetoric. If a speech is held 100 days closer to a general election, the level of emotive rhetoric increases by 0.015 . This effect may seem small, but the House of Commons is not a major arena for campaigning in the run-up to elections, as it closes 25 working days before general elections.

In order to strengthen the confidence in our results, we replicate our analysis with alternative dependent variables (see Appendices F and G). First, we use the share of emotive words. Furthermore, we create a measure based on the scaling procedure of Lowe et al. (2011) and we apply the LIWC dictionary (Pennebaker et al. 2015). We also run multilevel regression models clustering speeches into MPs and parties. In all cases, the difference between the level of emotive rhetoric in high-profile debates and the other debates remains statistically significant and robust.

Overall, and regardless of the measurement strategy or statistical specification, we confirm our expectation, namely that MPs are more likely to use emotive rhetoric in their legislative speeches when they face a larger public audience, such as during the PMQs and other high-profile debates.

\section{ALTERNATIVE MECHANISM: ISSUE-SPECIFIC AFFECT}

While our results are robust to different measures and statistical specifications, there could be a concern that alternative mechanisms could explain why MPs make more use of emotive rhetoric in some debates compared with others. Notably, it may be argued that rather than considering the likely audience, politicians use more emotive rhetoric when they talk about specific topics that are more emotive or polarizing in nature.

In this section, we discuss this alternative mechanism, and we show that it cannot account for our main finding; that is, politicians primarily use emotive rhetoric in high-profile debates that have a large audience. Of course, this does not mean that we can causally identify the effect of audience exposure on emotive rhetoric, but it does suggest that this is a plausible explanation for the patterns we are observing.

One might argue that some topics are simply more emotive than others. If such highly emotive topics are discussed more in high-profile debates, then the topic, and not the type of debate, will be driving up the level of emotive rhetoric. To examine this potential explanation, we check whether our results hold when we control for topics.

To do so, we use supervised learning to implement cross-domain classification of parliamentary speeches to topics (Osnabrügge, Ash, and Morelli 2020). We train a machine learning system on the annotated manifesto corpus (Krause et al. 2018) and then use the trained model to predict the topics of parliamentary speeches. We focus on seven main topics as defined by the manifesto project: economy, external relations, fabric of society, freedom and democracy, political system, social groups, and welfare and quality of life. ${ }^{16} \mathrm{We}$ use the python module scikit-learn to predict the topics of parliamentary speeches held in the House of Commons (Pedregosa et al. 2011). ${ }^{17}$ In Appendix H, we show how many speeches were classified to the topics over time.

We start by summarizing the average level of emotiveness by topic. ${ }^{18}$ Figure 4 shows the average level of emotive rhetoric across the seven topics. Not surprisingly, the highest (mean) emotiveness is found in speeches on the topic fabric of society, which includes discussions about the national way of life, traditional morality, and law and order. The second highest level of emotiveness is in speeches on social groups, which includes discussions about underprivileged minority groups, labor groups, and agriculture and farmers. Thereafter, we find speeches on welfare and quality of life, followed by external relations and the freedom and democracy, which cover discussions about human rights, democracy, and constitutionalism. Finally, speeches on the economy show the lowest level of emotive rhetoric.

In a subsequent step, we rerun our regression models with topic fixed effects. Table 4 summarizes the results. The effect of PMQs and Queen's Speech debates are statistically significant in all regression models at the 0.01 level. We find that the effect sizes are slightly smaller, but they are very similar to those from our main analysis. Model 1 shows, for example, that the level of emotive rhetoric increases by about 2.0 if the speech was held in PMQs. The effect of Urgent Questions is not robust. Therefore, this evidence strongly suggests that topics are not the main reason for the high levels of emotive rhetoric in PMQs and Queen's Speech debates. Appendix E includes the full regression output. In Appendix I we examine polarization as an alternative mechanism.

\section{GENERALIZABILITY: THE CASE OF IRELAND}

As one of the oldest parliaments in the world, the UK House of Commons provides an apposite case for the study of emotive rhetoric in parliamentary debates. The UK Parliament has served as a role model for parliaments around the world (e.g., Lijphart 1999). As a consequence, other democracies share a number of important institutional features with the UK (Bäck, Debus, and Fernandes Forthcoming). Nearly all advanced industrialized democracies have some form of question time, and similar to PMQs in the UK, oral

\footnotetext{
${ }^{16}$ We also include the category no topic, which includes speeches that do not belong to the seven substantive topics, such as procedural speeches. The manifesto project codes the no topic category as " 0 ." ${ }^{17}$ As an alternative, we also applied the unsupervised latent Dirichlet allocation model (Blei, Ng, and Jordan 2003). Our main regression results are robust, but the topics were difficult to interpret. Therefore, we decided to keep the analysis with cross-domain supervised learning.

${ }^{18} \mathrm{We}$ focus on the most likely topic for each category.
} 
FIGURE 4. Average Level of Emotive Rhetoric by Topic

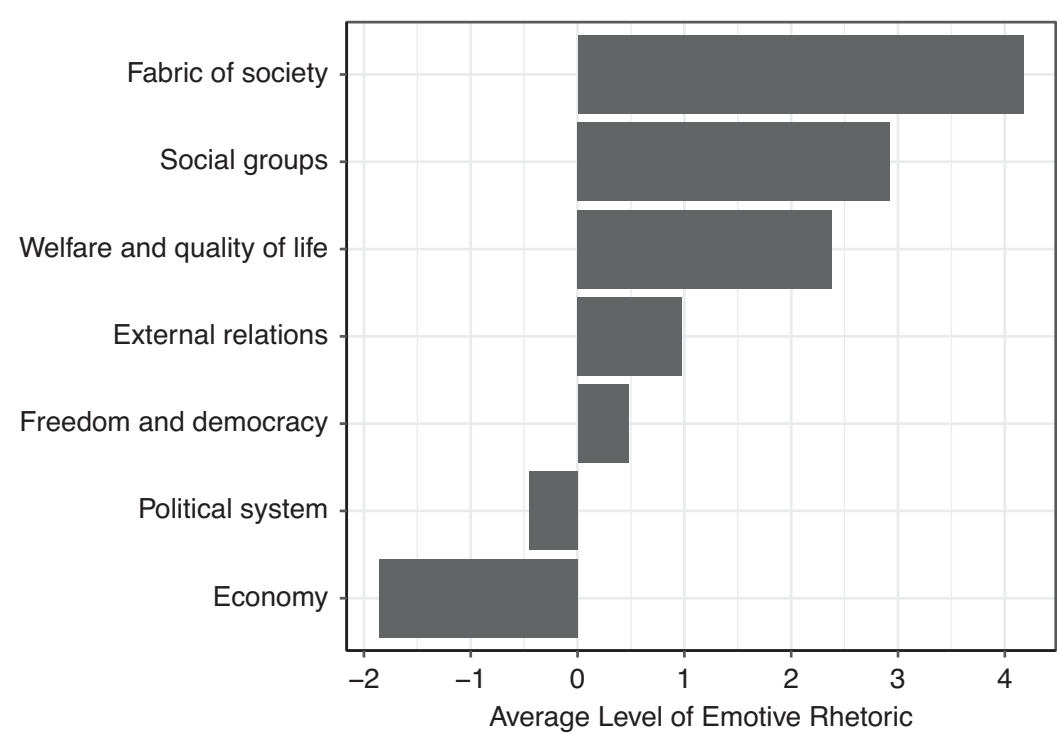

TABLE 4. Regression Analysis of Emotive Rhetoric with Topic Fixed Effects

\begin{tabular}{|c|c|c|c|c|c|}
\hline & (1) & (2) & (3) & (4) & (5) \\
\hline \multirow[t]{2}{*}{ PMQs } & $2.020^{\star \star}$ & $1.995^{\star \star}$ & $1.426^{\star \star}$ & $1.383^{\star \star}$ & $1.525^{\star \star}$ \\
\hline & $(0.156)$ & $(0.117)$ & $(0.143)$ & $(0.153)$ & $(0.208)$ \\
\hline \multirow[t]{2}{*}{ Queen's Speech Debate: Opening Day } & $2.298^{\star *}$ & $2.287^{\star \star}$ & $2.012^{* \star}$ & $2.132^{* \star}$ & $2.303^{\star *}$ \\
\hline & $(0.221)$ & $(0.216)$ & $(0.171)$ & $(0.201)$ & $(0.154)$ \\
\hline \multirow[t]{2}{*}{ Queen's Speech Debate: Other Days } & $0.554^{\star \star}$ & $0.605^{\star \star}$ & $0.491^{* \star}$ & $0.628^{\star \star}$ & $1.033^{\star *}$ \\
\hline & $(0.096)$ & $(0.094)$ & $(0.080)$ & $(0.087)$ & $(0.073)$ \\
\hline \multirow[t]{2}{*}{ Ministerial Question Time } & $-0.436^{\star *}$ & $-0.489^{\star \star}$ & $-0.539^{\star *}$ & $-0.492^{\star \star}$ & $-0.319^{\star *}$ \\
\hline & $(0.063)$ & $(0.061)$ & $(0.045)$ & $(0.060)$ & $(0.049)$ \\
\hline \multirow[t]{2}{*}{ Urgent Questions } & $0.390^{* \star}$ & -0.094 & $-0.168^{\star}$ & -0.068 & -0.111 \\
\hline & $(0.108)$ & $(0.097)$ & $(0.084)$ & $(0.091)$ & $(0.086)$ \\
\hline \multirow[t]{2}{*}{ Constant } & $0.908^{\star \star}$ & -0.069 & $-2.571^{\star \star}$ & $0.899^{+}$ & $-2.513^{\star *}$ \\
\hline & $(0.064)$ & $(0.089)$ & $(0.085)$ & $(0.517)$ & $(0.079)$ \\
\hline Linear time trend & & $\mathrm{x}$ & $\mathrm{x}$ & $\mathrm{X}$ & $\mathrm{x}$ \\
\hline MP fixed effects & & & $\mathrm{X}$ & & $x$ \\
\hline Controls & & & & $X$ & \\
\hline Weighting by speech length & & & & & $X$ \\
\hline Topic fixed effects & $\mathrm{X}$ & $\mathrm{X}$ & $\mathrm{X}$ & $\mathrm{X}$ & $\mathrm{X}$ \\
\hline$N$ & 958,925 & 958,925 & 958,925 & 958,925 & 958,925 \\
\hline$R^{2}$ & 0.048 & 0.052 & 0.078 & 0.057 & 0.158 \\
\hline
\end{tabular}

Note: Standard errors, clustered by speaker, in parentheses; ${ }^{+} p<0.10,{ }^{*} p<0.05,{ }^{* *} p<0.01$.

question times tend to receive high levels of publicity (Martin and Rozenberg 2012; Salmond 2014). For example, the Australian Parliament has a question time, which Dowding, Leslie, and Taflaga (Forthcoming) describe as "the peak of political theatre." Similarly, a form of PMQs was introduced for the German Chancellor in $2018 .{ }^{19}$ While each parliament has its

\footnotetext{
$\overline{19}$ https://www.theguardian.com/world/2018/jun/06/angela-merkelfirst-question-time-lacks-histrionics-uk-pmqs (last accessed on June $1,2020)$.
}

own idiosyncratic characteristics, they share the core feature examined in this paper-namely, that some debates are high-profile and likely to receive media and public attention, while others largely go unnoticed by the wider public (Martin and Rozenberg 2012). Yet, a key concern of our results is the external validity of our findings and the degree to which our conclusions can be generalized to other contexts.

In this section, we further examine the generalizability of our findings by studying the lower house of the Irish Parliament, the Dáil Éireann. We focus on Ireland 
TABLE 5. Regression Analysis of Irish Parliamentary Speeches

\begin{tabular}{|c|c|c|c|c|c|}
\hline & (1) & (2) & (3) & (4) & (5) \\
\hline Leaders' Questions & $\begin{array}{l}4.591^{\star \star} \\
(0.302)\end{array}$ & $\begin{array}{c}4.573^{\star *} \\
(0.296)\end{array}$ & $\begin{array}{l}3.975^{\star \star} \\
(0.249)\end{array}$ & $\begin{array}{l}3.792^{\star \star} \\
(0.263)\end{array}$ & $\begin{array}{c}2.497^{\star \star} \\
(0.243)\end{array}$ \\
\hline Constant & $\begin{array}{c}-3.404^{\star *} \\
(0.164)\end{array}$ & $\begin{array}{c}-3.577^{\star *} \\
(0.302)\end{array}$ & $\begin{array}{c}-3.209^{\star *} \\
(0.214)\end{array}$ & $\begin{array}{c}-2.429^{\star *} \\
(0.206)\end{array}$ & $\begin{array}{c}-1.929^{\star *} \\
(0.293)\end{array}$ \\
\hline $\begin{array}{l}\text { Linear time trend } \\
\text { MP fixed effects }\end{array}$ & & $\mathrm{X}$ & $\begin{array}{l}x \\
x\end{array}$ & $\mathrm{X}$ & $\begin{array}{l}x \\
x\end{array}$ \\
\hline Party fixed effects & & & & $\mathrm{X}$ & \\
\hline Controls & & & & $x$ & \\
\hline Weighting by speech length & & & & & $\mathrm{X}$ \\
\hline$N$ & 945,734 & 945,734 & 945,734 & 945,734 & 945,734 \\
\hline$R^{2}$ & 0.006 & 0.006 & 0.038 & 0.030 & 0.123 \\
\hline
\end{tabular}

for multiple reasons. First, the Irish Parliament is a good case to use to assess generalizability because it exhibits a number of institutional differences from the UK. For example, the Irish lower house uses singletransferable vote and not a first-past-the-post system as in the UK House of Commons (Gallagher 2006). Second, it allows us to apply the same English language dictionary as in the analysis of the UK House of Commons. Finally, the Irish Parliament has debates that, by design, vary in the public attention they receive.

We compare rhetoric in Dáil Leaders' Questions, as the most high-profile parliamentary debates, with rhetoric in other debates. Leaders' Questions were set up in 2001 and further amended in October 2002 (MacCarthaigh 2005; MacCarthaigh and Manning 2010). According to the Standing Order 36 (Dáil Éireann 2020), Leaders' Questions take place on Tuesdays, Wednesdays, and Thursdays. Opposition leaders have 32 minutes to ask questions to the prime minister. Leaders' Questions receive significant public attention and are televised by the public broadcasters, RTÉ One and RTÉ news. During 2018-2019, an average of $7 \%$ of those watching TV in Ireland followed the live broadcasting on RTÉ One. ${ }^{20}$ Other debates receive much less media and public attention.

We proceed in the same manner as in our analysis of the House of Commons and create a domain-specific dictionary of emotive and neutral words. Using the data of Herzog and Mikhaylov (2018), we focus on all speeches of at least 40 characters held in the lower house of the Irish Parliament from November 2002 until 2013. The dictionary includes 1,692 emotive and 1,764 neutral words. The dataset of parliamentary speeches includes meta-data on the ministerial positions of parliamentarians, the party, and the electoral cycle.

Table 5 summarizes our results. We run the same models as in our analysis of parliamentary debates in the House of Commons. In all models, the effect of Leaders' Questions is positive and statistically significant

\footnotetext{
${ }^{20}$ This information was provided by RTÉ One. Before July 2011, Leaders' Question only took place on Tuesdays and Wednesdays.
}

at the 0.01 level. The level of emotive rhetoric increases by 4.5 in Models 1 to 2 and by around 4 in Models 3 to 4 . In Model 5, the coefficient of the explanatory variable is slightly smaller because we weight the speeches by length. In Appendix E, we provide the complete results.

Overall, the evidence suggests that our results are generalizable beyond the British case.

\section{CONCLUSION}

This article has examined when and why parliamentarians use emotive rhetoric in parliamentary speeches. Recent research on emotions in political rhetoric has largely focused on how parties use positive and negative language in political campaigns (Crabtree et al. 2020; Kosmidis et al. 2019), but we know less about the use of emotive rhetoric in parliaments (Rheault et al. 2016; Slapin and Kirkland 2020). Previous work on legislative debates has analyzed intraparty politics by studying position taking and dissent expressed in parliamentary debates (Baumann, Debus, and Klingelhöfer 2017; Herzog and Benoit 2015; Martin and Vanberg 2008; Proksch and Slapin 2012). This study extends the literature on legislative behavior by focusing specifically on how politicians use emotional appeals in their speeches.

Our main argument is that politicians use emotive rhetoric primarily to appeal to voters. We therefore expect that the level of emotive rhetoric is especially high in high-profile debates, which have a large (electoral) audience. By contrast, in more low-profile debates where legislators are primarily addressing their fellow parliamentarian, they are less incentivized to use emotive rhetoric.

This article makes three main contributions to the literature on legislative debates and political speech. First, the findings of this study indicate that emotive rhetoric is used primarily when politicians think they are addressing not only their fellow parliamentarians but also voters. Our results thus support our main expectation, as we find a positive and statistically significant effect of high-profile debates-PMQs and 
Queen's Speech debates-on the use of emotive rhetoric. PMQs exhibit higher levels of emotive rhetoric than Ministerial Question Times, which supports our argument because Ministerial Question Times have a format similar to that of PMQs but receive less attention. We also provide evidence that these findings are generalizable to other countries that have similar parliamentary procedures, such as Ireland. Second, the study contributes to our understanding of how political behavior in parliamentary speeches differs across debates. Previous research argues that parliamentarians use speeches to appeal to voters. Our paper provides evidence that these incentives differ significantly across types of debates.

Third, we contribute to the literature on emotive rhetoric by applying a novel measurement technique of emotions in political text compared with the standard dictionary approach (Rice and Zorn 2019). Our measure of emotive rhetoric combines the ANEW dictionary and word-embedding techniques. We classify emotive and neutral words using the ANEW dictionary but further identify additional emotive and neutral words on the basis of the word vectors (Mikolov, Sutskever, et al. 2013). This procedure allows us to add the most emotive and neutral words that are used in parliamentary speeches, but are not included in the ANEW dictionary, to our domainspecific dictionary. Therefore, our measurement technique captures the use of emotive language in a political setting more precisely.

Overall, this study suggests that emotive rhetoric is a tool that politicians use to communicate their messages, especially when addressing voters, and we should study this alongside other political appeals, such as policy positions. This matters because we know from the literature on opinion formation that emotional appeals can have a range of effects on voters. Future research could further explore the implications of emotive rhetoric. Emotive parliamentary speeches may have positive implications by increasing political interest in the activities of representatives and in politics more generally. Yet, emotive rhetoric may also increase polarization and may favor politicians who prioritize emotional appeals over competent, coherent policy making. More generally, emotive rhetoric may have an influence on the quality of deliberation and, in turn, on the quality of democratic representation.

\section{SUPPLEMENTARY MATERIALS}

To view supplementary material for this article, please visit http://dx.doi.org/10.1017/S0003055421000356.

\section{DATA AVAILABILITY STATEMENT}

Research documentation and/or data that support the findings of this study are openly available at the American Political Science Review Dataverse: https://doi. org/10.7910/DVN/QDTLYV.

\section{ACKNOWLEDGMENTS}

For helpful comments and suggestions we thank Elliott Ash, Kenneth Benoit, Jack Blumenau, Lotte Hargrave, Ben Lauderdale, Sven-Oliver Proksch, Tom Robinson, Meg Russell, Jonathan Slapin, Katerina Tertytchnaya, Stephane Wolton, and our audiences at the EPSA conference, at Durham University, the IPERG-Universitat de Barcelona, the London School of Economics and Political Science, and the University College London. We thank Tom Hunter for excellent research assistance.

\section{FUNDING STATEMENT}

We acknowledge the generous funding from the European Research Council (ERC GA647835, EUDEMOS).

\section{CONFLICTS OF INTEREST}

The authors declare no ethical issues or conflicts of interest in this research.

\section{ETHICAL STANDARDS}

The authors affirm that this research did not involve human participants.

\section{REFERENCES}

Aalberg, Toril, and James Curran, eds. 2012. How Media Inform Democracy: A Comparative Approach. New York: Taylor \& Francis.

Arceneaux, Kevin. 2012. "Cognitive Biases and the Strength of Political Arguments.” American Journal of Political Science 56 (2): 271-85.

Atkins, Judi, Alan Finlayson, James Martin, and Nick Turnbull. 2014. Rhetoric in British Politics and Society. London: Palgrave Macmillan.

Bäck, Hanna, Marc Debus, and Jorge Fernandes, eds. Forthcoming. The Politics of Legislative Debates. Oxford: Oxford University Press.

Bakker, Bert N., Gijs Schumacher, and Matthijs Rooduijn. 2021. "Hot Politics? Affective Responses to Political Rhetoric." American Political Science Review 115 (1): 150-64.

Bates, Stephen, Peter Kerr, and Ruxandra Serban. 2018. Questioning the Government. In Exploring Parliament, eds. Cristina LestonBandeira and Louise Thompson, 174-86. Oxford: Oxford University Press.

Bates, Stephen R., Peter Kerr, Christopher Byrne, and Liam Stanley. 2014. "Questions to the Prime Minister: A Comparative Study of PMQs from Thatcher to Cameron." Parliamentary Affairs 41 (2): 499-525.

Baumann, Markus, Marc Debus, and Tristan Klingelhöfer. 2017. "Keeping One's Seat: The Competitiveness of MP Renomination in Mixed-member Electoral Systems." The Journal of Politics 79 (3): 979-94.

Betsy, Nicolas, and Tom Goldsmith. 2019. How Parliament Works. Abingdon: Routledge.

Bird, Steven, Ewan Klein, and Edward Loper. 2009. Natural Language Processing with Python. Sebastopol, CA: O'Reilly.

Black, Ryan C., Matthew E. K. Hall, Ryan J. Owens, and Eve M. Ringsmuth. 2016. "The Role of Emotional Language in Briefs before the US Supreme Court." Journal of Law and Courts 4 (2): 377-408. 
Blei, David M., Andrew Y. Ng, and Michael I. Jordan. 2003. "Latent Dirichlet Allocation." Journal of Machine Learning Research 3: 993-1022.

Bless, Herbert, Diane M. Mackie, and Norbert Schwarz. 1992. "Mood Effects on Attitude Judgments: Independent Effects of Mood before and after Message Elaboration." Journal of Personality and Social Psychology 63 (4): 585-95.

Blumenau, Jack. 2021. "The Effects of Female Leadership on Women's Voice in Political Debate." British Journal of Political Science 51 (2): 750-71.

Blumenau, Jack, and Roberta Damiani. Forthcoming. "The United Kingdom: The (Increasing) Discretion of MPs in Parliamentary Debates." In The Politics of Legislative Debates, eds. Hanna Bäck, Marc Debus, and Jorge Fernandes. Oxford: Oxford University Press.

Brader, Ted. 2005. "Striking a Responsive Chord: How Political Ads Motivate and Persuade Voters by Appealing to Emotions." American Journal of Political Science 49 (2): 388-405.

Bradley, Margaret M., and Peter J. Lang. 2017. "Affective Norms for English Words (ANEW)." Center for the Study of Emotion and Attention, Technical Report C-3 UF.

Bryan, Amanda C., and Eve M. Ringsmuth. 2016. "Jeremiad or Weapon of Words? The Power of Emotive Language in Supreme Court Dissents." Journal of Law and Courts 4 (1): 159-85.

Bull, Peter. 2002. Communication under the Microscope: The Theory and Practice of Microanalysis. London: Routledge.

Crabtree, Charles, Matt Golder, Thomas Gschwend, and Indridi H. Indridason. 2020. "It's Not Only What You Say It's Also How You Say It: The Strategic Use of Campaign Sentiment." The Journal of Politics 82 (3): 1044-60.

Crines, Andrew S. 2013. "An Analysis of George Galloway's Oratorical and Rhetorical Impact." Politics 33 (2): 81-90.

Crines, Andrew, and Tim Heppell. 2017. "Rhetorical Style and Issue Emphasis within the Conference Speeches of UKIP's Nigel Farage 2010-2014.” British Politics 12: 231-49.

Crines, Andrew, Tim Heppell, and Michael Hill. 2016. "Enoch Powell's 'Rivers of Blood' Speech: A Rhetorical Political Analysis." British Politics 11: 72-94.

Dáil Éireann. 2020. Standing Orders Relative to Public Business. February 17, 2020. https://data.oireachtas.ie/ie/oireachtas/ parliamentaryBusiness/standingOrders/dail/2020/2020-02-17_daileireann-standing-orders-relative-to-public-business-2020_en.pdf.

Damasio, Antonio. 2000. The Feeling of What Happens: Body and Emotion in the Making of Consciousness. London: Vintage.

Dietrich, Bryce J., Matthew Hayes, and Diana Z. O'Brien. 2019. "Pitch Perfect: Vocal Pitch and the Emotional Intensity of Congressional Speech." American Political Science Review 113 (4): 941-62.

Dowding, Keith, Patrick Leslie, and Marija Taflaga. Forthcoming. Australia: Speaker Time in an Adversarial System. In The Politics of Legislative Debates, eds. Hanna Bäck, Marc Debus, and Jorge Fernandes. Oxford: Oxford University Press.

Downs, Anthony. 1957. An Economic Theory of Democracy. New York: Harper.

Eggers, Andrew, and Arthur Spirling. 2014. "Ministerial Responsiveness in Westminster Systems: Institutional Choices and House of Commons Debate 1832-1915." American Journal of Political Science 58 (4): 873-87.

Eichorst, Jason, and Nick Lin. 2019. "Resist to Commit: Concrete Campaign Statements and the Need to Clarify a Partisan Reputation." The Journal of Politics 81 (1): 15-32.

Finlayson, Alan, and James Martin. 2008. “It Ain't What You Say ...': British Political Studies and the Analysis of Speech and Rhetoric." British Politics 3 (4): 445-64.

Gallagher, Michael. 2006. Ireland: The Discreet Charm of PR-STV. In The Politics of Electoral Systems, eds. Michael Gallagher and Paul Mitchell, 511-34. Oxford: Oxford University Press.

Gennaro, Gloria, and Elliott Ash. 2021. "Emotion and Reason in Political Language." Center for Law \& Economics Working Paper Series 02/2021. Zurich: Center for Law \& Economics, ETH Zurich.

Gerholm, Tove. 2018. "From Shrieks to 'Stupid Poo': Emotive Language in a Developmental Perspective." Text \& Talk 38 (2): 137-65.

Grimmer, Justin, and Brandon M. Stewart. 2013. "Text as Data: The Promise and Pitfalls of Automatic Content Analysis Methods for Political Texts." Political Analysis 21 (3): 267-97.
Griskevicius, Vladas, Michelle N. Shiota, and Samantha L. Neufeld. 2010. "Influence of Different Positive Emotions on Persuasion Processing: A Functional Evolutionary Approach." Emotion 10 (2): 190-206.

Groenendyk, Eric. 2011. "Current Emotion Research in Political Science: How Emotions Help Democracy Overcome its Collective Action Problem." Emotion Review 3 (4): 455-63.

Groenendyk, Eric W., and Antoine J. Banks. 2014. "Emotional Rescue: How Affect Helps Partisans Overcome Collective Action Problems." Political Psychology 35 (3): 359-78.

Hager, Anselm, and Hanno Hilbig. 2020. "Does Public Opinion Affect Elite Rhetoric?" American Journal of Political Science 64 (4): 921-37.

Heath, Mirjana. 2017. "Emotive Use of Language in Annual Municipal Financial Reports." Master's thesis. Royal Roads University, British Columbia, Canada.

Herzog, Alexander, and Kenneth Benoit. 2015. "The Most Unkindest Cuts: Speaker Selection and Expressed Government Dissent during Economic Crisis." The Journal of Politics 77 (4): 1157-75.

Herzog, Alexander, and Slava J. Mikhaylov. 2018. "Database of Parliamentary Speeches, 1919-2013." Paper presented at the 2017 International Conference on the Frontiers and Advances in Data Science October 23-25, Xi'an, China.

Hibbing, John R. 1986. "Ambition in the House: Behavioral Consequences of Higher Office Goals among US Representatives." American Journal of Political Science 30 (3): 651-65.

Holmes, Marcus. 2015. "Believing This and Alieving That: Theorizing Affect and Intuitions in International Politics." International Studies Quarterly 59 (4): 706-20.

House of Commons. 2019. "Standing Orders (in force on 6 November 2019).” UK Parliament. https://publications.parliament.uk/ $\mathrm{pa} / \mathrm{cm} 201919 / \mathrm{cmstords} / 341 / \mathrm{so} 341051119$ web.pdf.

Høyland, Bjørn, Sara B. Hobolt, and Simon Hix. 2019. "Career Ambitions and Legislative Participation: The Moderating Effect of Electoral Institutions.” British Journal of Political Science 49 (2): 491-512.

Hutton, Mark, David Natzler, Matthew Hamlyn, Colin Lee, Chloe Mawson, Crispin Poyser, Eve Samson, et al. 2019. Erskine May: Parliamentary Practice. London: LexisNexis.

Jung, Jae-Hee. 2020. "The Mobilizing Effect of Parties' Moral Rhetoric." American Journal of Political Science 64 (2): 341-55.

Kelly, Richard. 2015. "Prime Minister's Questions." House of Commons Library SN/PC/05183: 1-12.

Koschut, Simon, Todd H. Hall, Reinhard Wolf, Ty Solomon, Emma Hutchison, and Roland Bleiker. 2017. "Discourse and Emotions in International Relations." International Studies Review 19 (3): 481-508.

Kosmidis, Spyros, Sara B. Hobolt, Eamonn Molloy, and Stephen Whitefield. 2019. "Party Competition and Emotive Rhetoric." Comparative Political Studies 52 (6): 811-37.

Krause, Werner, Pola Lehmann, Jirka Lewandowski, Theres Matthieß, Nicolas Merz, and Sven Regel. 2018. Manifesto Corpus. Version: 2018-2. Berlin: WZB Berlin Social Science Center.

Kühne, Rinaldo, Christian Schemer, Jörg Matthes, and Werner Wirth. 2011. "Affective Priming in Political Campaigns: How Campaign-induced Emotions Prime Political Opinions." International Journal of Public Opinion Research 23 (4): 485-507.

Lijphart, Arend. 1999. Patterns of Democracy: Government Forms and Performance in Thirty-six Democracies. New Haven, CT: Yale University Press.

Lin, Nick, and Moritz Osnabrügge. 2018. "Making Comprehensible Speeches when your Constituents Need it." Research \& Politics 5 (3): 1-8.

Lowe, Will, Kenneth Benoit, Slava Mikhaylov, and Michael Laver. 2011. "Scaling Policy Preferences from Coded Political Texts." Legislative Studies Quarterly 36 (1): 123-55.

Macagno, Fabrizio, and Douglas Walton. 2014. Emotive Language in Argumentation. Cambridge: Cambridge University Press.

MacCarthaigh, Muiris. 2005. Accountability in Irish Parliamentary Politics. Dublin: Institute of Public Administration.

MacCarthaigh, Muiris, and Maurice Manning, eds. 2010. The Houses of the Oireachtas: Parliament in Ireland. Dublin: Institute of Public Administration.

Maltzman, Forrest, and Lee Sigelman. 1996. "The Politics of Talk: Unconstrained Floor Time in the U.S. House of Representatives." The Journal of Politics 58 (3): 819-30. 
Martin, Lanny W., and Georg Vanberg. 2008. "Coalition Government and Political Communications." Political Research Quarterly 61 (3): 502-16.

Martin, Shane, and Olivier Rozenberg, eds. 2012. The Roles and Function of Parliamentary Questions. London: Routledge.

Mayhew, David R. 1974. Congress: The Electoral Connection. New Haven, CT: Yale University Press.

Mikolov, Tomas, Kai Chen, Greg Corrado, and Jeffrey Dean. 2013. "Efficient Estimation of Word Representations in Vector Space." Paper presented at the International Conference on Learning Representations, Scottsdale, AZ.

Mikolov, Tomas, Ilya Sutskever, Kai Chen, and Greg Corrado, and Jeffrey Dean. 2013. "Distributed Representations of Words and Phrases and Their Compositionality." Advances in Neural Information Processing Systems 26: 3111-19.

Nai, Alessandro, and Jürgen Maier. 2018. "Perceived Personality and Campaign Style of Hillary Clinton and Donald Trump." Personality and Individual Differences 121: 80-3.

Norton, Philip. 2013. Parliament in British Politics. Basingstoke: Palgrave Macmillan.

Osnabrügge, Moritz, Elliott Ash, and Massimo Morelli. 2020. "Measuring Topics Using Cross-domain Supervised Learning: Methods and Application to New Zealand Parliament." Center for Law \& Economics Working Paper Series 04/2020. Zurich: Center for Law \& Economics, ETH Zurich.

Osnabrügge, Moritz, Sara B. Hobolt, and Toni Rodon. 2021. "Replication Data for: Playing to the Gallery: Emotive Rhetoric in Parliaments." Harvard Dataverse. Dataset. https://doi.org/10.7910/ DVN/QDTLYV.

Pedregosa, Fabian, Gael Varoquaux, Alexandre Gramfort, Vincent Michel, Bertrand Thirion, Olivier Grisel, Mathieu Blondel, et al. 2011. "Scikit-learn: Machine Learning in Python." Journal of Machine Learning Research 12: 2825-30.

Pennebaker, James W., Roger J. Booth, Ryan L. Boyd, and Martha E. Francis. 2015. "Linguistic Inquiry and Word Count: LIWC2015." Austin, TX: Pennebaker Conglomerates (www. LIWC.net).

Peterson, Andrew, and Arthur Spirling. 2018. "Classification Accuracy as a Substantive Quantity of Interest: Measuring Polarization in Westminster Systems." Political Analysis 26 (1): 120-28.

Ponder, J. D., and Paul Haridakis. 2015. "Selectively Social Politics: The Differing Roles of Media Use on Political Discussion." Mass Communication and Society 18 (3): 281-302.

Prior, Alex. 2018. "Getting the Story Right: A Constructivist Interpretation of Storytelling in the Context of UK Parliamentary Engagement." Politics and Governance 6 (4): 83-94.

Prior, Alex, and Yuri van Hoef. 2018. "Interdisciplinary Approaches to Emotions in Politics and International Relations." Politics and Governance 6 (4): 48-52.

Proksch, Sven-Oliver, and Jonathan B. Slapin. 2012. "Institutional Foundations of Legislative Speech." American Journal of Political Science 56 (3): 520-37.

Proksch, Sven-Oliver, Will Lowe, Jens Wäckerle, and Stuart Soroka. 2019. "Multilingual Sentiment Analysis: A New Approach to Measuring Conflict in Legislative Speeches." Legislative Studies Quarterly 44 (1): 97-131.

Redlawsk, David P. 2006. Feeling Politics: Emotion in Political Information Processing. New York: Palgrave Macmillan.

Redlawsk, David P., and Douglas R. Pierce. 2017. "Emotions and Voting." In The SAGE Handbook of Electoral Behaviour, eds. Kai Arzheimer, Jocelyn Evans, and Michael S. Lewis-Beck, 406-32. London: Sage.

Řehưrek, Radim, and Petr Sojka. 2010. Software Framework for Topic Modelling with Large Corpora. In Proceedings of the LREC 2010 Workshop on New Challenges for NLP Frameworks, 45-50. Valletta, Malta: ELRA.

Renshon, Jonathan, Jooa Julia Lee, and Dustin Tingley. 2015. "Physiological Arousal and Political Beliefs." Political Psychology 36 (5): 569-85.

Rheault, Ludovic, and Christopher Cochrane. 2020. "Word Embeddings for the Analysis of Ideological Placement in Parliamentary Corpora." Political Analysis 28 (1): 112-33.
Rheault, Ludovic, Kaspar Beelen, Christopher Cochrane, and Graeme Hirst. 2016. "Measuring Emotion in Parliamentary Debates with Automated Textual Analysis." PLoS ONE 11 (12): e0168843.

Rice, Douglas R., and Christopher Zorn. 2019. "Corpus-based Dictionaries for Sentiment Analysis of Specialized Vocabularies." Political Science Research and Methods 9 (1): 20-35.

Rocklage, Matthew D., Derek D. Rucker, and Loran F. Nordgren. 2018. "Persuasion, Emotion, and Language: The Intent to Persuade Transforms Language via Emotionality." Psychological Science 29 (5): 749-60.

Rodriguez, Pedro L., and Arthur Spirling. Forthcoming. "Word Embeddings: What Works, What Doesn't, and How to Tell the Difference for Applied Research.” The Journal of Politics. https:// www.journals.uchicago.edu/doi/10.1086/715162.

Ryan, Timothy J. 2012. "What Makes Us Click? Demonstrating Incentives for Angry Discourse with Digital-age Field Experiments." The Journal of Politics 74 (4): 1138-52.

Salmond, Rob. 2014. "Parliamentary Question Times: How Legislative Accountability Mechanisms Affect Mass Political Engagement." The Journal of Legislative Studies 20 (3): 321-41.

Scalia, Antonin, and Bryan A. Garner. 2008. Making Your Case: The Art of Persuading Judges. St. Paul, MN: Thomson.

Sinclair, Robert C., Melvin M. Mark, and Gerald L. Clore. 1994. "Mood-related Persuasion Depends on (Mis)Attributions." Social Cognition 12 (4): 309-26.

Slapin, Jonathan B., and Justin H. Kirkland. 2020. "The Sound of Rebellion: Voting Dissent and Legislative Speech in the UK House of Commons.” Legislative Studies Quarterly 45 (2): 153-75.

Slapin, Jonathan B., Justin H. Kirkland, Joseph A. Lazzaro, and Patrick A. Leslie. 2018. "Ideology, Grandstanding, and Strategic Party Disloyalty in the British Parliament." American Political Science Review 112 (1): 15-30.

Spirling, Arthur. 2016. "Democratization and Linguistic Complexity: The Effect of Franchise Extension on Parliamentary Discourse, 1832-1915." The Journal of Politics 78 (1): 120-36.

Steiner, Jürg, André Bächtiger, Markus Spörndli, and Marco R. Steenbergen. 2005. Deliberative Politics in Action: Analyzing Parliamentary Discourse. Cambridge: Cambridge University Press.

Turney, Peter D., and Michael L. Littman. 2003. "Measuring Praise and Criticism: Inference of Semantic Orientation from Association." ACM Transactions on Information Systems 21 (4): 315-46.

Valentino, Nicholas A., Vincent L. Hutchings, Antoine J. Banks, and Anne K. Davis. 2008. "Is a Worried Citizen a Good Citizen? Emotions, Political Information Seeking, and Learning via the Internet." Political Psychology 29 (2): 247-73.

Van Kleef, Gerben A., Helma van den Berg, and Marc W. Heerdink. 2015. "The Persuasive Power of Emotions: Effects of Emotional Expressions on Attitude Formation and Change." Journal of Applied Psychology 100 (4): 1124-42.

Victor, Jennifer N. 2011. "Legislating versus Campaigning: The Legislative Behavior of Higher Office-seekers." American Politics Research 39 (1): 3-31.

Weber, Christopher. 2013. "Emotions, Campaigns, and Political Participation." Political Research Quarterly 66 (2): 414-28.

Weeks, Brian E. 2015. "Emotions, Partisanship, and Misperceptions: How Anger and Anxiety Moderate the Effect of Partisan Bias on Susceptibility to Political Misinformation." Journal of Communication 65 (4): 699-719.

Wirz, Dominique. 2018. "Persuasion through Emotion? An Experimental Test of the Emotion-eliciting Nature of Populist Communication." International Journal of Communication 12: 1134-38.

Yeung, Lorrita. 2007. "In Search of Commonalities: Some Linguistic and Rhetorical Features of Business Reports as a Genre." English for Specific Purposes 26 (2): 156-79.

Young, Lori, and Stuart Soroka. 2012. "Affective News: The Automated Coding of Sentiment in Political Texts." Political Communication 29 (2): 205-31. 